access to the C.N.S. at this time have developed overt C.N.S. disease the rate of onset of this complication will fall. For the present series such a fall occurred during the third year (Fig. 1), a finding also noted by others (Haghbin and Zuelzer, 1965; Evans et al., 1970).

A correlation between high total leucocyte count at presentation and increased incidence of C.N.S. complications has been reported (Melhorn et al., 1970). A high leucocyte count is likely to be associated not only with the access of a relatively large number of cells to the C.N.S. at the time of seeding but also with a higher rate of replication of the cells within the C.N.S. For both these reasons the higher the leucocyte count the earlier symptoms of C.N.S. disease might be expected. Our findings bear out this expectation in that they show (Fig. 3) that the difference in incidence rate between patients with leucocyte counts above and below $10,000 / \mathrm{mm}^{3}$ is confined to the first 10 months, after which the rate of onset of C.N.S. disease is independent of initial leucocyte count. The leucocyte count thus appears to affect chiefly the time of onset of C.N.S. disease. The association of lymph-node enlargement with increased incidence cannot be explained by correlation with the leucocyte count; indeed, the association persists throughout the course of the disease (Fig. 4). We have no explanation for this effect.

The increasing frequency of C.N.S. leukaemia in recent years has usually been attributed to longer survival and increasing diagnostic awareness, but a possible contributory effect of newer drugs has also been suggested (Evans et al., 1970). The method of analysis we have used on our data shows that the higher proportion of patients affected in 1966-70 cannot be completely explained in terms of increasing survival in more recent years. Diagnostic awareness of this complication may have increased over the years, but examination of available necropsy records suggests that undiagnosed C.N.S. disease was not more common in this hospital during the earlier period. It therefore seems unlikely that underdiagnosis explains the difference between the two periods. If the increase is at least partly real the possibility must be considered that recent more intensive systemic chemotherapy has played a contributory part, perhaps through immunosuppression.
The use of prophylactic regimens for C.N.S. leukaemia is increasing (Melhorn et al., 1970; Aur et al., 1971; Medical Research Council, 1971). We conclude from this study that prophylaxis stands a greater chance of success if used very soon after diagnosis, when leukaemic cells have already gained access to the C.N.S. but are still present there in relatively small numbers. Furthermore, in assessing the results of any prophylactic trial, allowance must be made for the effect of differences in initial leucocyte and platelet counts and in lymphnode enlargement between treatment groups. Finally, if prophylaxis is not to be used on all patients, the identification of a high-risk group with initial high blood leucocyte count, thrombocytopenia, and lymph-node enlargement will enable a useful selection to be made.

This work was supported by grants from the Medical Research Council and the Leukaemia Research Fund. We wish to thank Mrs. Gail Raynsford, Mrs. D. Bull, and Mrs. B. Crossley for help with computation, and Mrs. Bull for drawing the figures. We should also like to thank the director and staff of the Science Council's Atlas computer at Chilton for providing us with such excellent computer facilities.

\section{References}

Aur, R. J. A., et al. (1971). Blood, 37, 272.

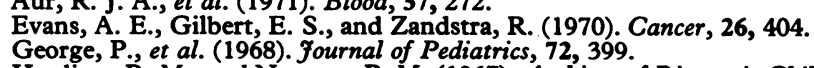

Hardisty, R. M., and Norman, P. M. (1967). Archives of Disease in Childhood, $42,441$.

Hardisty, R. M., and Till, M. M. (1968). Archives of Disease in Childhood, $43,107$.

Haghbin, M., and Zuelzer, W. W. (1965). Fournal of Pediatrics, 67, 23.

Johnson, R. E. (1964). Fournal of the National Cancer Institute, 32, 1333.

Johnson, R. E. (1964). Fournal of the National Cancer Instu
Mantel, N. (1966). Cancer Chemotherapy Reports, 50, 163.

Medical Research Council (1971). British Medical Journal, 4, 189.

Melhorn, D. K., Gross, S., Fisher, B. J., and Newman, A. J. (1970). Blood, 36, 55.

Peto, R., and Peto, J. (1972). Fournal of the Royal Statistical Society. Series $A$.

135, 185.
Steffy, J. M. (1962). Fournal of Pediatrics, 60, 183.

\title{
Comparison of Beclomethasone Dipropionate Aerosol and Prednisolone in Reversible Airways Obstruction
}

\author{
S. LAL, \\ D. M. HARRIS, \\ K. K. BHALLA, \\ S. N. SINGHAL, \\ A. G. BUTLER
}

British Medical fournal, 1972, 3, 314-317

\section{Summary}

This paper describes a double-bind crossover trial of prednisolone and beclomethasonc dipropionate aerosol in 38 steroid-dependent patients with reversible diffuse airways obstruction. Altogether there was no difference

\section{General Hospital, Bury, Lancs}

S. LAL, M.B., F.R.C.P., Consultant Physician

K. K. BHALLA, M.D., M.R.C.P., Registrar

S. N. SINGHAL, M.B., M.R.C.P., Clinical Assistant

Research Division, Allen and Hanburys Limited, Ware, Herts

D. M. HARRIS, M.B., D.OBST.R.C.O.G., Head of Medical Services A. G. BUTLER, B.SC., Clinical Trials Officer, Medical Services in the patient's preference of the two treatment groups or in the number of times they used their bronchodilator aerosol, or in the forced expiratory volume in one second, vital capacity, or peak expiratory flow rate in the two treatment groups. The plasma cortisol levels when the patients were on the aerosol were much higher than when they were on prednisolone. The use of inhaled aerosol steroids seems to be preferable as it eliminates the usual complications of oral steroid therapy.

\section{Introduction}

Corticosteroids are an established treatment for asthma, and doses up to $7 \mathrm{mg}$ of prednisolone may be sufficient to keep patients symptom-free. Even after prolonged use the risk of pituitary-adrenal axis suppression is minimal (Robinson et al., 1962). When taken by mouth, however, they act systemically 
and patients are exposed to the many and sometimes fatal effects of corticosteroids (Nielsen et al., 1963).

Frequent attempts to discover whether asthma could be controlled and side effects reduced by administering corticosteroids by inhalation have been described. Gelfand (1951) reported good control of asthma after the use of a wet aerosol solution of cortisone acetate at a daily dose of $50 \mathrm{mg}$. Brockbank et al. (1956) and Morrison Smith (1958) were unsuccessful in controlling asthma using an aerosol solution of hydrocortisone hemisuccinate. Other investigators using hydrocortisone acetate as an aerosol powder reported symptomatic improvement in asthma (Foulds et al. 1955; Brockbank and Pengelly, 1958; Hajos, 1958; Helm and Heyworth, 1958; Herxheimer et al., 1958). No objective measurements of respiratory function or tests of adrenal function were made in these studies. But Langlands and McNeill (1960) using hydrocortisone hemisuccinate powder in an objective double-blind study found no improvement. Franklin et al. (1958) and Peters and Henderson (1958) reported a clinical improvement after the use of prednisolone phosphate aerosol.

The use of dexamethasone-sodium-21 phosphate aerosol has been described by many workers (Arbesman et al., 1963; Snider et al., 1963; Dennis and Itkin, 1964; Siegel et al., 1964; Novey and Beall, 1965; Toogood and Lefcoe, 1965; Kravis and Lecks, 1966; Taub, 1966), all of whom reported good control of respiratory function. Nevertheless, persistent signs of Cushing's syndrome (Novey and Beall, 1965), biochemical evidence of adrenal suppression (Siegel et al., 1964), side effects of corticosteroids, and masking of the symptoms of allergic rhinitis and atopic skin conditions (Toogood and Lefcoe, 1965) indicated significant systemic absorption, suggesting that this aerosol has no advantage over a systemic steroid.

A new steroid aerosol, beclomethasone dipropionate, appears to have considerable advantages over those preparations investigated during the past 20 years. It is a potent topical steroid, having a high index of activity when applied to the skin (Caldwell et al., 1968). No adrenal suppression has been seen after the application of therapeutic quantities of beclomethasone dipropionate topically (Raffle and Frain-Bell, 1967, 1968). A further local site of action, where the characteristics of the steroid could be useful, is the bronchial mucous membrane.

This paper reports a double-blind crossover trial, comparing beclomethasone dipropionate administered by aerosol, prednisolone given by mouth, and their placebos.

\section{Materials and Method}

Beclomethasone dipropionate was administered by a pressurized aerosol delivering a metered dose of $50 \mu \mathrm{g}$ of micronized powder per puff. The average particle size delivered was $5 \mu \mathrm{m}$.

Forty patients ( 31 female and 9 male) aged 14-60 years (average age 39 years) who had reversible airways obstruction and were being maintained with bronchodilators and prednisolone up to $7.5 \mathrm{mg} /$ day were chosen. Thirty-one patients were also receiving disodium cromoglycate. Previous attempts to discontinue the prednisolone had been unsuccessful.

At the start of the trial the patients were allocated at random to two groups. One group received beclomethasone dipropionate aerosol $100 \mu \mathrm{g}$ three times a day plus placebo prednisolone tablets for one month, followed by prednisolone tablets $(2 \mathrm{mg}$ in the morning and $5 \mathrm{mg}$ at night) and a placebo beclomethasone dipropionate aerosol for a month. The other group had these treatments in the reverse order. To establish whether the patients needed the prednisolone all active treatment was discontinued in the third month, making this final period a single-blind study. Each patient was seen on entering the trial and at the end of each month, when forced expiratory volume in one second $\left(F_{E V}\right)$, vital capacity (VC), and peak expiratory flow rate (PEFR) were measured and a blood sample was taken for plasma 11-hydroxycorticosteroid (henceforth referred to as plasma cortisol) estimation by the method described by Mattingly (1962). All blood samples were collected between 10 a.m. and 12 noon. The appointment time for the patients was the same for each visit, and the samples were collected within 10 minutes of this time to avoid any discrepancy due to diurnal rhythm of plasma cortisol.

Each patient was provided with a Wright peak flow meter and instructed in its use, and the readings taken every morning, afternoon, and evening were recorded. They were also asked to keep a record of the number of times they had to use their bronchodilator aerosol each day. Each patient was instructed in the correct use of a pressurized aerosol and were all proficient in firing the aerosol at the beginning of inspiration so that the drug had the best possible chance of being carried in the airstream into the lungs. They were also instructed to contact any one of three of us (S.L., K.K.B., S.N.S.) during the month if they were not well. During the third month most of the patients were unable to continue the placebo treatment for the whole period. As this third month was not randomized and was single-blind, and as few patients completed the enrire month without requiring steroid therapy again, no attemr: vas made to carry out a statistical analysis as this would be meaningless. The figures are included in the tables, however, for the sake of completion.

\section{Results}

The 38 patients who completed the trial were questioned at the end of each month about their subjective preference. Altogether 7 patients found inhaled beclomethasone dipropionate much better than oral prednisolone, 8 found it better, 14 found it the same, 6 found it worse, and 3 found it much worse. Overall 15 patients preferred the aerosol, and 9 the oral prednisolone. There was thus no tendency for one treatment to be preferred to the other $(P>0 \cdot 1)$. This is borne out by the daily peak flow readings recorded by the patients and the $\mathrm{FEV}_{1}$ recorded during their attendance at the clinic.

TABLE I-Forced Expiratory Volume in One Second

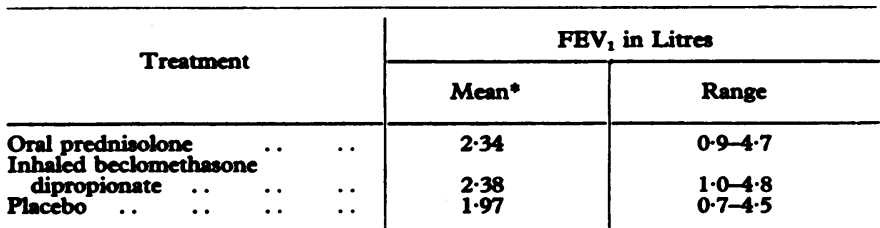

- Each mean calculated from 38 single readings, the single reading being the best of the three acceptable records.

TABLE II-Vital Capacity

\begin{tabular}{|c|c|c|}
\hline \multirow{2}{*}{ Treatment } & \multicolumn{2}{|c|}{ VC in Litres (B.T.P.S.) } \\
\hline & Mean* & Range \\
\hline $\begin{array}{l}\text { Oral prednisolone } \\
\text { Inhaled beclomethasone dipropionate } \\
\text { Placebo } \\
\text { Plo }\end{array}$ & $\begin{array}{l}3 \cdot 48 \\
3 \cdot 54 \\
3 \cdot 20\end{array}$ & $\begin{array}{l}1 \cdot 5-5 \cdot 9 \\
2 \cdot 0-5 \cdot 7 \\
1 \cdot 2-5 \cdot 9\end{array}$ \\
\hline
\end{tabular}

* Each mean calculated from 38 single readings, the single reading being the best of three acceptable records. B.T.P.S. = Body temperature, pressure, and saturation.

The values for mean $\mathrm{FEV}_{1}, \mathrm{VC}$, and PEFR during each treatment period are given in Tables I, II, and III, and show that the two active treatments were equally effective.

The mean weekly PEFR throughout the period of the study and the diurnal variation are shown in Fig. 1. Each broken line 
TABLE III-Daily Peak Expiratory Flow Measurements recorded by the Patients

\begin{tabular}{|c|c|c|c|}
\hline \multirow{2}{*}{ Time of Day } & \multirow{2}{*}{ Treatment } & \multicolumn{2}{|c|}{ PEFR (L./min) } \\
\hline & & Mean* & Range \\
\hline $\begin{array}{ll}\text { Morning } & \ldots \\
& . \\
\text { Afternoon } & \ldots \\
\text { Evening } & \text {.. }\end{array}$ & $\begin{array}{l}\text { Prednisolone } \\
\text { Beclomethasone dipropionate } \\
\text { Placebo } \\
\text { Prednisolone } \\
\text { Beclomethasone dipropionate } \\
\text { Placebo } \\
\text { Prednisolone } \\
\text { Beclomethasone dipropionate } \\
\text { Placebo }\end{array}$ & $\begin{array}{l}281 \\
288 \\
249 \\
304 \\
312 \\
278 \\
293 \\
310 \\
275\end{array}$ & $\begin{array}{l}124-501 \\
125-532 \\
115-457 \\
144-556 \\
138-572 \\
106-490 \\
139-501 \\
150-538 \\
106-468\end{array}$ \\
\hline
\end{tabular}

-Each mean calculated from 28 peak expiratory flow readings for each treatment period in 38 cases, the period being less in some cases during placebo treatment (see period in

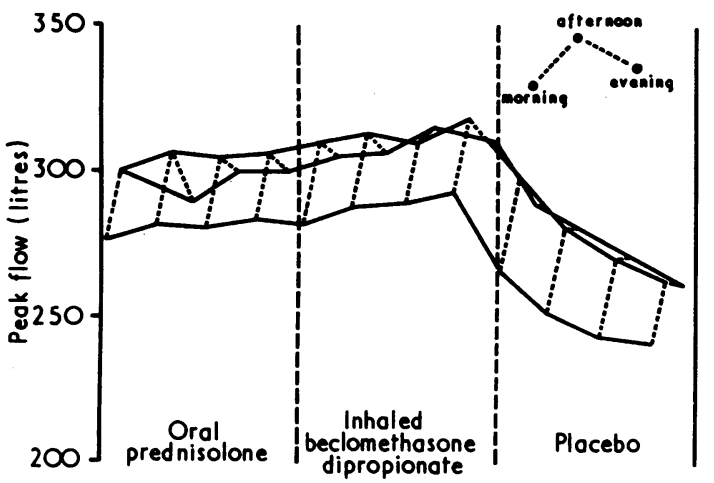

FIG. 1-Mean weekly peak expiratory flow rate.

represents the weekly mean PEFR readings of the three times of the day, thus showing detailed distribution over the whole period of the study.

The use made of bronchodilators during the three-month period is shown in Table IV. It is significant that during the third month of the study, which was single-blind only, the condition of the patients deteriorated despite increasing the other drugs they were receiving.

The mean plasma cortisol levels of the patients are given in Table V. The biochemist responsible for plasma cortisol

TABLE IV-Bronchodilator Usage during Period of Study

\begin{tabular}{l|c|c}
\hline & \multicolumn{2}{|c}{ No. of Times/Day } \\
\cline { 2 - 4 } & Mean & Range \\
\hline When receiving prednisolone (7 mg/day) $\ldots$ \\
When receiving beclomethasone dipropionate $(300 \mu \mathrm{g} /$ day $)$ & $\begin{array}{l}1.5 \\
1.6\end{array}$ & $\begin{array}{l}0-4.5 \\
0-4.5\end{array}$ \\
When receiving placebo $\ldots \ldots$ & 2.2 & $0-7.0$ \\
\hline
\end{tabular}

TABLE v-Plasma Cortisol Levels

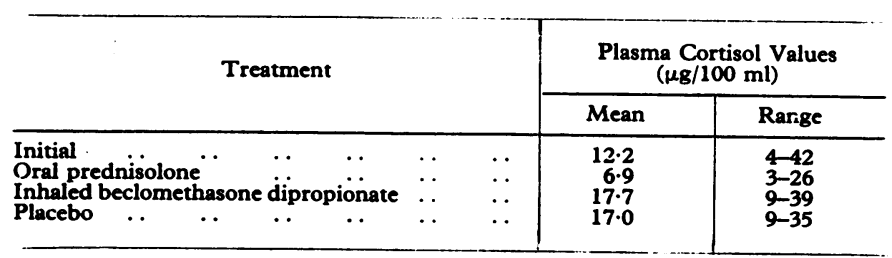

estimation was not aware of the patients' medication. The difference in cortisol values between the two active treatments is highly significant. In each patient the value during oral treatment was lower than the value after the use of the aerosol $(P<0.001)$. The individual changes in plasma cortisol values are shown in Fig. 2. Six patients had similar levels. (Two patients $4 \mu \mathrm{g} / 100 \mathrm{ml}$ before and $14 \mu \mathrm{g} / 100 \mathrm{ml}$ after treatment, two patients $4 \mu \mathrm{g} / 100 \mathrm{ml}$ before and $20 \mu \mathrm{g} / 100 \mathrm{ml}$ after treatment, two patients $4 \mu \mathrm{g} / 100 \mathrm{ml}$ before and $11 \mu \mathrm{g} / 100 \mathrm{ml}$ after treatment, two patients $5 \mu \mathrm{g} / 100 \mathrm{ml}$ before and $9 \mu \mathrm{g} / 100 \mathrm{ml}$ after treatment, two patients $5 \mu \mathrm{g} / 100 \mathrm{ml}$ before and $20 \mu \mathrm{g} / 100$ $\mathrm{ml}$ after treatment, and two patients $9 \mu \mathrm{g} / 100 \mathrm{ml}$ before and 16 $\mu \mathrm{g} / 100 \mathrm{ml}$ after treatment.)

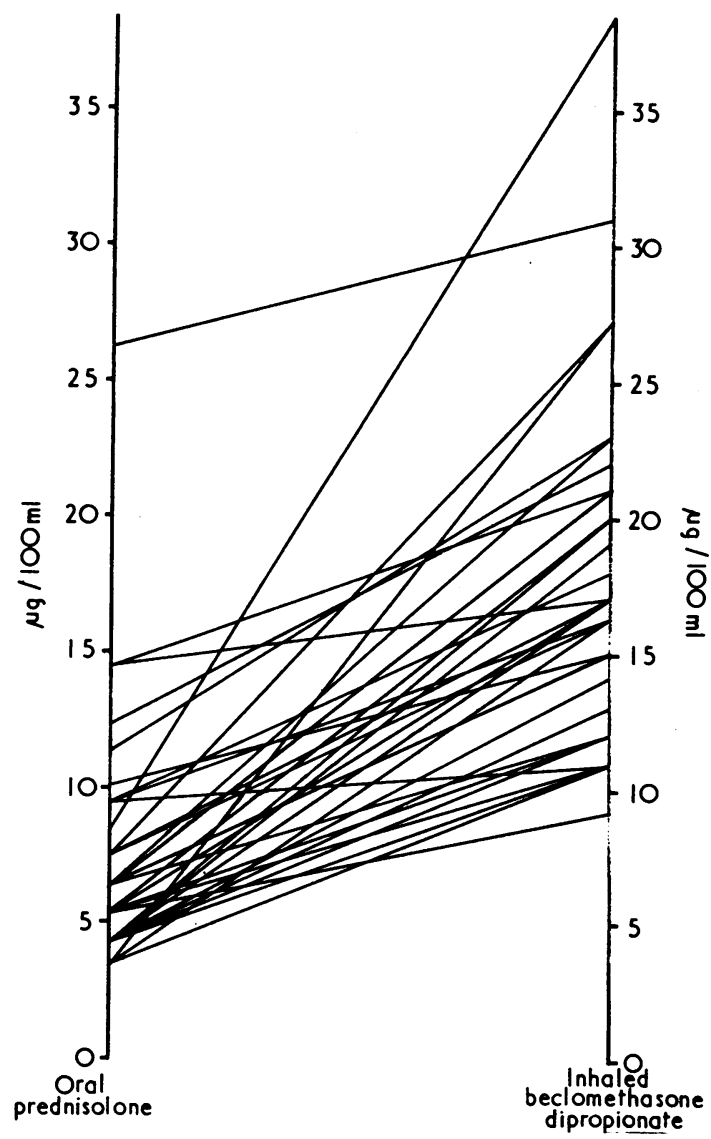

FIG. 2-Plasma cortisol values in the 38 patients. Five patients had identical levels.

\section{Discussion}

From the objective measurements made-FEV, VC, PEFRand from the patients' opinion and usage of the bronchodilator aerosol it seems that patients can be maintained on $300 \mu \mathrm{g} /$ day of beclomethasone dipropionate aerosol just as well as on $7 \mathrm{mg}$ / day of prednisolone. On the other hand there is a noticeable difference in the plasma cortisol levels between the two treatment groups. From the plasma cortisol levels obtained during the placebo period it can be concluded that there is no long-term suppression of the pituitary-adrenal axis. It may take up to 48 hours, however, for the actual recovery (Robinson et al., 1962), thus apart from complications like osteoporosis, bleeding from peptic ulcer, etc. inherent in oral steroid therapy, the obvious disadvantage of adrenal suppression during the period of therapy is eliminated by the use of beclomethasone dipropionate aerosol at the dosage used in this trial $(300 \mu \mathrm{g} /$ day $)$.

Previous experience with steroid aerosols in asthma has been disappointing, largely because side effects from corticosteroid therapy were not eliminated. All the previously-tried steroid aerosols were prepared from steroids with weak topical antiinflammatory effects but potent systemic effects. Beclomethasone dipropionate is a highly-active topical steroid with weak systemic effects. By exerting a selective, topical, anti-inflammatory effect on the bronchial mucous membrane it is able, as this trial shows, to control asthma as well as prednisolone given by mouth. In 
healthy volunteers who received up to $4 \mathrm{mg}$ of beclomethasone dipropionate by mouth and $2 \mathrm{mg}$ by inhalation for periods of 48 hours, their 24-hour urinary 17-oxogenic excretion rate remained within normal limits (Harris, 1972). The inhaled dose in the volunteer study was over six times the dose which in this trial successfully controlled the patients' asthma, as the FEV VC, and PEFR measurements show. The patients' bronchodilator requirements were identical whether they were receiving oral or inhaled steroids and so was their preference for the two treatments. From the study the use of inhaled aerosol steroid seems to be preferable to oral prednisolone in the management of reversible diffuse airways obstruction requiring long-term, low-dose steroid therapy.

We are grateful to Mr. A. J. Davey, of Messrs. Allen and Hanburys Limited, who carried out the statistical analysis, the staff of the pulmonary function laboratory for the ventilatory capacities, and Mr. G. Crossley for the biochemical analysis. The beclomethasone dipropionate aerosols, prednisolone tablets, and placebo were kindly supplied by Messrs. Allen and Hanburys Limited.

\section{References}

Arbesman, E. C., Bonstein, H.S., and Reisman, R. E. (1963). Fournal of Allergy, 34, 354.

Brockbank, W., Brebner, H., and Pengelly, C. D. R. (1956). Lancet, 2, 807.
Brockbank, W., and Pengelly, C. D. R. (1958), 1, 187.

Caldwell, I. W., et al. (1968). British Fournal of Dermatology, 80, 111.

Dennis, M., and Itkin, I. H. (1964). Fournal of Allergy, 35, 70.

Foulds, W. S., Greaves, D. P., Herxheimer, H., and Kingdom, L. G. (1955).

Lancet, 1, 234.
Franklin, W., Lowell, F. C., Michelson, A., and Schiller, I. W. (1958). Fournal of Allergy, 29, 214.

Gelfand, M. L. (1951). New England Fournal of Medicine, 245, 293.

Hajos, M. K. (1958). British Medical fournal, 2, 1226.

Harris, D. M. (1972). In preparation.

Helm, W. H., and Heyworth, F. (1958). British Medical fournal, 2, 765.

Herxheimer, H., McAllen, M. K., and Williams, D. A. (1958). British Medical fournal, 2, 768 .

Kravis, L. P., and Lecks, H. I. (1966). American fournal of Diseases of 768.

Kravis, L. P., and Lecks, H. I. (1966). American fournal of Diseases of Children, 111, 343

Langlands, J. H., and McNeill, R. S. (1960). Lancet, 2, 404.

Mattingly, D. (1962). Fournal of Clinical Pathology, 15, 374

Mielsen, J. B., Drivsholm, A. A., Fischer, F., and Brochner-Mortensen, K. (1963). Acta Medica Scandinavica, 173, 177 .

Novey, H. S., and Beall, G. (1965). Archives of Internal Medicine, 115, 602. Peters, G. A., and Henderson, L. L. (1958). Proceedings of the Staff Meetings of the Mayo Clinic, 33, 57.

Raffle, E. J., and Frain-Bell, W. (1967). British fournal of Dermatology, 79, 487.

Raffle, E. J., and Frain-Bell, W. (1968). British fournal of Dermatology, 80, 124.

Robinson, B. H. B., Mattingly, D., and Cope, C. L. (1962). British Medical Fournal, 1, 1579.

Siegel, S. C., Heimlich, E. M., Richards, W., and Kelly, V.C. (1964). Pediatrics, 33, 245.

Smith, J. Morrison (1958). Lancet, 2, 1248.
Snider, G. L. et al. (1963). Diseases of the Chest, 44, 408.

Taub, S. J. (1966). Ear, Nose and Throat Monthly, 45, 103.

Toogood, J. H., and Lefcoe, N. M. (1965). Fournal of Allergy, 36, 321.

\title{
Genetic Variants of von Willebrand's Disease
}

\author{
L. HOLMBERG， I. M. NILSSON
}

British Medical fournal, 1972, 3, 317-320

\section{Summary}

A specific antiserum against an antihaemophilic factor (AHF)-related plasma protein was raised in rabbits. $A$ quantitative immunochemical method was used to determine the amount of this protein present in the plasma of 33 patients with haemophilia $A$ and 70 patients with von Willebrand's disease. The protein probably consisted of AHF residing in or complexed with the von Willebrand factor. The patients with von Willebrand's disease were shown to fall into two separate genetic groups, one with decreased and one with normal amounts of the AHF-related protein. The patients with haemophilia $A$ had normal amounts of the protein in their plasma.

\section{Introduction}

von Willebrand's disease is a haemorrhagic disorder characterized by a low plasma content of antihaemophilic factor (AHF; factor VIII) and a prolonged bleeding time (Nilsson et al., 1957a). According to Salzman (1963) the platelet adhesiveness is often decreased, but the platelets themselves are normal (Nilsson et al., 1957b; Larrieu et al., 1968). The prolonged bleeding time in

\footnotetext{
Coagulation Laboratory and Paediatric Clinic, University of Lund, Malm6 Allmánna Sjukhus, Malmó, Sweden

von Willebrand's disease is due to the absence of a plasma factor, the von Willebrand factor. Infusion of this factor both corrects the bleeding time and stimulates synthesis of or activates AHF. The factor is present in the plasma of normal subjects and patients with haemophilia $A$ and can be recovered in fraction $\mathrm{I}-\mathrm{O}$ and cryoprecipitate as well as in other concentrates of plasma (Nilsson et al., 1959; Creveld and Mochtar, 1960; Cornu et al., 1961; Bennett and Dormandy, 1966).

The mode of inheritance of von Willebrand's disease has been regarded as autosomal and dominant, but with varying penetrance and with varying expressivity (Nilsson and Blombäck, 1962).

The presence of AHF-related antigenic material has recently been shown in plasma from patients with haemophilia $A$, but with varying frequency (Hoyer and Breckenridge, 1968; Bennett and Huehns, 1970; Meyer and Larrieu, 1971; Stites et al., 1971; Zimmerman et al., 1971). Stites et al. and Zimmerman et al. found little or no such immunologically reactive material in six and 11 patients with von Willebrand's disease respectively.

We have raised an antiserum against a high-molecular-weight protein, probably consisting of a complex between the von Willebrand factor and AHF. We found this AHF-related protein to be present in normal amounts in the plasma of 33 patients with haemophilia $\mathrm{A}$, but 70 patients with von Willebrand's disease fell into two separate genetic groups, one with decreased and one with normal amounts of AHF-related protein.

\section{Materials and Methods}

Blood was collected with the silicone technique and citrated plasma was prepared as described by Nilsson et al. (1970). The plasma was stored at $-60^{\circ} \mathrm{C}$ until used. 